\title{
Village Financial Management Towards Village Fund Policy For Community Empowerment
}

\author{
Hastuti \\ ${ }^{1}$ Department of Management, Fakulty Economics, Universitas Muhammadiyah Buton, South \\ Sulawesi, Indonesia \\ * Corresponding author: \\ Email: tutie977@.gmail.com
}

\begin{abstract}
.
The goal of this study is to explain Village Fund Allocation for community empowerment by concentrating on village financial management rules in Village Fund Allocation administration. The Village Fund Allocation Implementation Team's financial management was not in accordance with applicable regulations, thus this research was conducted. This study is expected to assist the Buton Regency Government, specifically the South Lasalimu District, in improving village financial management. The research was conducted through in-depth interviews and direct observation of Village Fund Management implementation. According to the study's results, accountable and transparent management has been in place for the planning and implementation of Village Fund Allocation activities. Meanwhile, in terms of accountability, as indicated by the physical outcomes, it has exhibited responsible and transparent execution; nevertheless, additional direction is still necessary on the administrative side, since it is not completely in conformity with the regulations. The main barrier is the ineffectiveness of developing village government officials and human resource capabilities, which results in a lack of ongoing assistance from local government officials.
\end{abstract}

Keywords: Financial Management, Policy, Village Fund, Community Empowerment.

\section{INTRODUCTION}

Village finance is inextricably linked to government, society, and development, thus several key concepts must be addressed. First, financial management is not only the authority of the village government, but it also belongs to the rights of the community, because it requires community participation in APBDesa planning, the community needs to know the village's financial situation transparently, and the village government is required to be financially responsible. Second, in the government sector, village funds should be used not just to pay civil officials' wages, but also to improve civil servants' human resources. Third, communal fields must be included in the village programme and get enough financial assistance. [1] Village governments can provide capital to communities from a variety of sources, including monies from the Regional Revenue and Expenditure Budget (APBD). The Village Fund Allocation (ADD) is a fund that provides $10 \%$ of the Regional Revenue and Expenditure Budget (APBD). The Allocation of Community Funds (ADD) is directed to villages to assist development initiatives customised to each village's requirements.[2] According to the method above, the planning for the use of village 
finances is incorporated in the Village Revenue and Expenditure Budget (APBDesa), which is as follows:

1. Thoughts on Village Development

The Musrenbangdes is a local government-organized forum for organising activities based on priority requirements. The village musrebang was conducted in July of the current fiscal year, with various members of the community, religious leaders, traditional authorities, and the sub-district head serving as village coach in attendance.

2. Work Plan for Development (RKP) The village RKP includes strategies for the implementation of village administration, development, and the empowerment of local residents. The village RKP includes a review of the previous year's RKP, programme priorities, activities, and village finances administered by third parties, as well as authority delegation from higher government levels. The RKP is completed no later than September preceding the current fiscal year since it serves as the foundation for the village income and spending budget.

3. Revenue and Expenditure in the Village

Budget for Revenue and Expenditure in the Village The Budget Plan is created once the Development Work Plan (RKP) has been completed. The Village RAPB is submitted to the Regent via the Camat; if accepted by the Regent, the Village RAPB is ratified as APBDesa by the village authority.

4. Revenue and Expenditure in the Village

The Village BudgetRevenue and Expenditure Budget is the activity's source of revenue and expense. Village funds are one of the sources of revenue in APBDesa. [3]

Village government is placed as a subsystem of the Indonesian government administration structure, thus villages have the authority, responsibilities, and responsibility to control and manage the interests of their own people. A source of village revenue is required to carry out the authority, duties, and obligations of the village in the administration of government and development. The Village Fund is 30 percent for the village government, which is used for operating expenditures, allowances, and official travel costs from the village government, according to Regulation of the Regent of Buton Regency Number 12 of 2015. Meanwhile, 70\% of the Village Fund (DD) is used for community empowerment and increasing the Village Government's ability.[4] From the specifics of the Village Fund (DD), it is important to have effective management from the village government so that its execution may be in compliance with the Village Fund's goals and objectives. The Village Head, the Technical Implementer of Village Financial Management (PTPKD), and the Village Treasurer are all expected to comprehend and manage Village Fund Allocation. In the process of managing the Village Fund in the village Kinapani Makmur subdistrict South Lasalimu Buton, village governments are confronted with conditions of society's low education level and low managerial level village officials, as stated by the village 
chief Kinapani Makmur subdistrict South Lasalimu Buton. "Accountability in All Forms" I controlled the Kinapani Makmur village's financial reports since the Village Secretary (Village Apparatuseducation )'s level was low and he did not comprehend. Input of data, computer technological issues, and management accounting (Kinapani Makmur Village Head, 2019)

As a result, the community must be convinced of the relevance, success rate, and community benefit of the targeted programs/activities, including education. Infrastructure as well as health. Village funds are a source of assistance from the government as well as a mandate for the growth and empowerment of communities in a village, where the aid is used as a community facility in expanding and enhancing a village's productivity. That is, as one of the institutions that contributed to the kepemerintahan model, the village's government funding is integrally linked to facility development and rural empowerment.[5] Due of the low quality of human resources in the environment, this group is not subject to monitoring. [6] In order for the Village Fund to continue to support village development, community empowerment, and assistance implementation.

\section{METHODS}

This research employs a qualitative method, namely through gathering, recording, and processing data or information to be investigated and evaluated. When conducting research in the field related to the management of village fund programmes for village communities, this research method is presented directly between researchers and informants, and it is more sensitive and can adapt to the research setting on the value patterns encountered to explore meanings, various variations, and perceptual understanding, which are then analysed qualitatively (a case study in Kinapani Makmur Village, South Lasamu District, Buton Regency). Data and fact-based research that seeks to offer a description of a phenomena or situation. The goal of a true investigation is to discover the truth. [7]

\section{RESULT AND DISCUSSION}

In this situation, one of the sources of revenue for the village of Kinapani Makmur, South Lasamu District, Buton Regency, which comes from the Village Fund (DD), is Rp. 270,500,194, Fiscal Year 2019. Table 1 displays the data.

\section{Table 1:}

Data on the Budget Work Plan for the Implementation of Kinapani Makmur Development, South Lasalimu District, Buton Regency Village Funds (APBN) 2019

\begin{tabular}{|c|l|c|c|c|}
\hline No & Activity & Volume & Unit Costs & Ceiling \\
\hline 1 & Construction of Gate & 5 & $3,500,000$ & $17,500,000$ \\
\hline
\end{tabular}


International Journal Of Science, Technology \& Management

\begin{tabular}{|c|l|c|r|r|}
\hline 2 & $\begin{array}{l}\text { Construction of Coastal Concrete Sirings } \\
\text { in Kinapani Makmur Village }\end{array}$ & 1 & $168,892,981$ & $168,892,981$ \\
\hline 3 & Road repairs & 6 & $12,351,202.1$ & 74.107 .213 \\
\hline 4 & Bimtek & 2 & $5,000,000$ & $10,000,000$ \\
\hline \multicolumn{2}{|c|}{ Total } & $270,500,194$ \\
\hline
\end{tabular}

Source: Kinpani Makmur Village Head Office 2019

The use of Village Funds (DD) for community empowerment is greater than operational. This is done because $70 \%$ of the Village Fund (DD) is intended for community empowerment and $30 \%$ for the operation of the village government.[8]

The Village Fund, which is used for village community empowerment, is aimed at improving or developing village physical facilities and infrastructure, such as small-scale public facilities and environmental improvements and roads, as well as honoraria for the Village Fund Implementation Team and strengthening village institutions, as well as other village activities deemed urgent. Meanwhile, the Village Fund's administration of village government is designed to assist village government implementation and the functioning of the Village Consultative Body. Buton Regency BPMPD Buton Regency BPMPD Buton Regency BPMPD Buton Regency BPMPD But.Kinapani Makmur Village is still trailing behind communities in the South Lasalimu sub-district in terms of development, as seen by inadequate village development, as one example of road infrastructure development. Schools as well as Community Health Centers. The Kinapani Makmur Village Government prioritises infrastructure development in the village development planning process drawn from the Village Fund Program, in accordance with the Tri Dharma of Buton Regency Development, namely infrastructure, education, and health. Kinapani Makmur Village, Buton Regency, South Lasamu, Village Funds (APBN) in 2019.

According to the following information, the Government of Buton Regency is committed to increasing community participation: "The current district government does provide opportunities for the community to play a more active role in development, beginning with planning, implementing, controlling, and evaluating as well as post-activities.

"This was done only to put into practise the core notion of increasing involvement through community empowerment. We will not wait for smart individuals, but this is a community learning media project that requires support from district government authorities. In particular, ADD planning strategies are fully left to village community debate; the district administration simply offers guidelines for the use of money in order to minimise misappropriation and to synchronise regional development initiatives. The most essential aspect is that the musrenbangdes forum serves as a vehicle for 
community learning in development management." (Results of a 20th of October, 2019 interview with MU)

According to MU's informant, about the government's commitment to increasing community involvement, AM, a technical official in the development of ADD in the sub-district.

"We adopt district-level policies to offer lessons to the village community so that they are better empowered to manage development in their individual villages based on the requirements of the community." This ADD programme truly encourages village community empowerment, but at the sub-district level, we simply enable as needed to ensure that we do not depart from the Regent's Regulation on Implementation Guidelines." (On the 20th of October, 2019, AM conducted an interview.)

ADD is a source of village revenue that is linked to the Village Revenue and Expenditure Budget (APBDes). As a result, programme planning and activities are developed in collaboration with the Village Development Planning Deliberation forum (Musrenbangdes). The Musrenbangdes is a forum for village-level discussion of proposed development activity plans informed by the concepts of Village Community Participation Development Planning (P3MD). This principle necessitates community participation in decision making and defining the development to be carried out, particularly those based in the village in question, in order to properly respond to changing needs/aspirations.

The application of the participation concept has also been demonstrated by the results of interviews: "All members of the BPD I are required to attend every village development meeting. Except to study along with sub-district and village authorities, and to participate in choosing what development will take place in the community." (The outcome of an interview with KB on October 31, 2019)

According to the informant, "the development planning system from the bottom (bottom up planning) starts at the lowest community level at the village level, which is the embodiment of involvement and absorption of community goals.

"As a result, the community must be involved in decision making at all times. Giving the community more chances is a fundamental notion for recognising the community as development actors, which is really done in the ADD programme. Meanwhile, the technical agency in charge will respond to the importance of cross-village and sub-district activities that emerge from village deliberations." (The outcome of an interview with SP on October 21, 2019)

This process is a steady endeavour that simultaneously gives chances or space for communal ambitions. as a vehicle for community education on the idea of responsibility in the management of village budget allocations These is reinforced by 
the informant's statement: "Village gatherings like this may also be utilised as a tool to deliberate together on how to make this village better.

"Furthermore, from an organisational standpoint, the community has learnt a great deal about respecting other people's perspectives and sacrificing personal interests for the sake of the community as a whole." (Results of an interview with MY conducted on October 24, 2019)

The Village Implementation Team is solely responsible for the implementation of programmes funded by ADD. Every physical activity must have an activity information board erected at the activity area to encourage openness and clear information delivery to the public. The name of the activity, the volume of the activity, the amount of the budget from ADD and non-governmental organisations, and the time of the activity must all be included on the information board. In addition to the activity nameplate, information on all ADD programmes must be given at the village office, where the village community may access it. These two actions were taken in order to put the concept of transparency in village development into action, so that the community may freely learn about the ADD programme and give criticism and recommendations to the Village Implementation Team for the improvement of ADD management.

"The village administration is obligated to disclose information to the larger community, so that the community can make criticism and recommendations for the perfection of the execution of the village's level of participation." (The outcome of an interview with AS on October 21, 2019)

Village financial management must be carried out in an efficient and effective manner, as well as in a transparent and accountable manner. ADD, which is one of the primary sources of income for the village, must also be openly responsible to the community and to the government at the highest level as the organisation that grants power. Accountability to the community is carried out on a three-monthly basis through an ADD implementation review forum headed by the Village Head.

"For the sake of openness in ADD management, we encourage BPD, LPMD, and community leaders to review the execution of the ADD programme that I have created every three months" (Results of interview with SRT, on October 24, 2019).

The evaluation of the ADD program's implementation also encourages the community to actively engage in offering feedback and corrections to the ADD program's implementation. In this instance, the village administration must also reply to community corrections on the forum in order to achieve perfection in ADD implementation. Furthermore, the evaluation forum has used the principles of openness in ADD accountability on a regular basis. In terms of financial administration management, the following interview results: "Proof of spending money must be provided in every accountability report. 
"Not only that, but it must also be accompanied by additional supporting evidence. As the Village Implementation Team is in charge of ADD management, this must be completed. However, several villages have yet not adopted this provision. That is the situation that we, as the sub-district government, have an obligation to correct, as a guide for accountability excellence. (The following are the findings of an interview with EP on October 20, 2019)

According to the findings of the research, the accountability system for managing village budget allocations in the South Lasalimu sub-district is founded on the principles of accountability and responsibility, but not entirely in compliance with current regulations. As a result, it is important to make continual improvements while still adapting to the environment and conditions, as well as the evolution of the current rules and regulations. Village expenditure by group and category includes:

1. Village Administration ImplementationThe Community

The village administration administration fund is presented as 62.21 percent of the total income in the attachment to the Budget Report and Realization of Budget, which is not in accordance with the Ministry of Home Affairs regulation, which states that the administration fund should only be 30 percent of the total income. The spending funds for village administration had an increase in funds of Rp. $80,538,902$ during the current quarter.

2. Village Development Implementation

In the attachment to the Budget Report and Realization of APBDesa, village development funds are planned to incur an extra cost of Rp. 316,526,600 to Rp. $2,322,961,818$ in the current term.

3. Development of the Village Community Village

The village community development fund is budgeted at Rp. 592,329,446 in the current term, with a reduction in spending for community development of Rp. $124,534,600$ to Rp. $467,794,846$ in the attachment to the Budget Report and Realization of the Budget.

4. Empowerment of the Village Community.

The community empowerment fund is budgeted at Rp. 397,899,600 in the current term, with extra funds ranging from $\mathrm{Rp} 22,169,098$ to $\mathrm{Rp} 420,068,698$ in the attachment to the Budget Report and Realization of the Budget.

5. Unanticipated Expenses

Unexpected funds were planned for Rp. 146,648,326 in the current period, with an extra Rp. 300,000 to Rp. 146,948,326 in the attachment to the Budget Report and Realization of APBDesa.

The building of agricultural road infrastructure is funded by village finances and is done in phases. Farm roads are desperately required to assist community agricultural operations. Because the road that the community generally takes is still tough for 
farmers, because the road they use is still an insufficient path. As is well known, the majority of the inhabitants of Kinapani Makmur Village work as farmers, cultivating rice, rubber plantations, vegetables, and other crops. The development of agricultural roads has aided the farming community in making agricultural operations more accessible to farmers. Farmers' passion for farming grows when agricultural road infrastructure is built, since access to farming areas is easier to reach by car. Because of the ease of access, this facility motivates farmers to be more excited about their job. Development of Clean Water The most fundamental necessity for daily living is clean water. Starting with drinking water sources, cooking, cleaning, and other activities all require clean water. The status of rural communities that continue to rely heavily on the river for various bathing activities, drinking water, and washing has resulted in increased water pollution, and deteriorating river water quality can have a detrimental influence on people's lives. To improve the efficacy of the village development programme, the Village Fund Policy may be successfully implemented by adopting village financial management. [9]

\section{CONCLUSION}

Accountability of Village Fund Allocation Management in South Lasalimu District, Buton Regency, some conclusions can be drawn as follows.

1. The planning of the ADD (Village Fund Allocation) program in 12 villages throughout the South Lasalimu Sub-district has gradually implemented the concept of participatory development of rural communities as evidenced by the application of participatory, responsive, and transparent principles. for learning village community resources in order to realize village community empowerment through the Musrenbangdes forum (Village Development Planning Deliberation).

2. The implementation of the ADD (Village Fund Allocation) program in South Lasalimu District has implemented the principles of participatory, responsive, and transparent. Although the application of the principle of accountability at this stage is still limited to physical accountability, the administrative side is still not fully implemented perfectly.

3. The accountability of ADD, both technically and administratively, is good, but in terms of financial administration accountability, the competence of human resource managers is the main obstacle, so it still requires assistance from local government officials to adjust rules changes every year.

4. The Village Fund Allocation Program is an ideal concept for the Buton Regency Government in the context of implementing participatory development of rural communities, in fact it has received a positive response from the community which is highly expected for its sustainability in order to increase rural development. 


\section{ACKNOWLEDGMENTS}

Regards and gratitude to the Chancellor of the University Muhammadiyah Buton have sent to support this study, as well as express my heartfelt gratitude and appreciation to colleagues, to inform, and all parties who have aided the author's analysis in the research process.

\section{REFERENCES}

[1] K. A. K. Saputra, "IMPLEMENTASI TOTAL QUALITY MANAGEMENTDALAM PENGELOLAAN KEUANGAN DESA,” pp. 99-117, 2019.

[2] R. N. Sari, H. Ribawanto, and M. Said, "Pengelolaan Alokasi Dana Desa dalam Perspektif Pemberdayaan Masyarakat,” J. Adm. Publik, vol. 3, no. 11, pp. 1880-1885, 2008.

[3] Y. Hulu, R. Hamdani, H. Muhammad, and A. Nasution, "Jurnal Pendidikan Ilmu-Ilmu Sosial Pengelolaan Dana Desa dalam Pemberdayaan Masyarakat Desa," vol. 10, no. 1, pp.146-154,2018, [Online]. Available: http://jurnal.unimed.ac.id/2012/index.php/jupiis.

[4] A. Suryani, "Manajemen Pengelolaan Dana Desa," J-MAS (Jurnal Manaj. dan Sains), vol. 4, no. 2, p. 348, 2019, doi: 10.33087/jmas.v4i2.117.

[5] G. Y. R. Mamelo, L. K. Kalangi, and Linda Lambey, "Analisis pelaksanaan dan penatausahaan dana desa pada desa-desa dalam wilayah Kecamatan Kotamobagu Timur, Kota Kotamobagu,” J. Ris. Akunt. dan Audit. “Goodwill,” vol. 7, no. 2, pp. 148-159,2016,[Online].Available:

https://ejournal.unsrat.ac.id/index.php/goodwill/article/view/13558/13144.

[6] Y. P. Feni and S. Susi, "Analisis Pengelolaan Alokasi Dana Desa Dalam Pemberdayaan Masyarakat Desa Karangluhur Kabupaten Wonosobo," J. Public Policy Manag. Rev., vol. 7, no. 1, p. 96, 2018.

[7] J. Lexi and M. M.A., "Metodologi Penelitian Kualitatif. In Metodologi Penelitian Kualitatif,"RakeSar.,pp.54-68,2010,[Online].Available: https://scholar.google.com/citations?user=O-B3eJYAAAAJ\&hl=en.

[8] R. Lesmana, N. Sunardi, W. Hasbiyah, M. Tumanggor, and Susantol, "Manajemen Alokasi Dana Desa dalam Upaya dan Strategi Mewujud-kan Desa Sejahtera Mandiri di Desa Cihambulu, Kec. Pabuaran, Kab. Subang, Jawa Bara,” vol. 1, no. 1, pp. 57-65, 2019.

[9] L. N. Fahri, "Pengaruh Pelaksanaan Kebijakan Dana Desa terhadap Manajemen Keuangan Desa dalam Meningkatkan Efektifivitas Program Pembangunna Desa," J. Publik, vol. 11, no. 1, pp. 75-88, 2017, doi: 10.2337/db11-0654. 